\title{
ChemComm
}

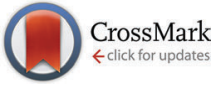

Cite this: Chem. Commun., 2015, 51, 1305

Received 10th September 2014 Accepted 27th November 2014

DOI: $10.1039 / \mathrm{c} 4 \mathrm{cc} 07003 \mathrm{~h}$

www.rsc.org/chemcomm

\section{Development of benzo[1,4]oxazines as biofilm inhibitors and dispersal agents against Vibrio cholerae $\dagger$}

\author{
Christopher J. A. Warner, ${ }^{a}$ Andrew T. Cheng, ${ }^{\mathrm{b}}$ Fitnat H. Yildiz ${ }^{\mathrm{b}}$ and \\ Roger G. Linington ${ }^{* a}$
}

\begin{abstract}
Bacterial biofilms are estimated to be associated with over 65 percent of all nosocomial infections. However, no therapeutics have been approved by the FDA which directly mediate biofilm formation or persistence. Herein we report oxazine $\mathbf{2 5}$ as a highly potent inhibitor, disperser and in the presence of the appropriate antibiotic eradicator of $V$. cholerae biofilms.
\end{abstract}

Bacterial biofilms are surface associated bacterial communities of sessile cells encased in a matrix of polysaccharides, extracellular DNA and proteins. ${ }^{1}$ Such biofilms are of significant concern in nosocomial infections, where it is attributed to over $\$ 1$ billion in increased hospital costs per annum in the US alone. ${ }^{2}$ Unlike cells in the planktonic state, bacterial biofilms do not exert their antimicrobial resistance through mutation or acquisition of resistance functions by horizontal gene transfer. ${ }^{3}$ Instead, resistance is largely driven by the formation of latent cells within the biofilm matrix that reduce cellular turnover and therefore remove the susceptibility of targets associated with traditional antimicrobials. ${ }^{4}$

$V$. cholerae is a diarrheal pathogen that naturally inhabits both fresh and saltwater environments. ${ }^{5}$ In spite of its prevalence, no clinical therapeutics have been approved for use in the US or elsewhere that directly target biofilm formation and persistence. A limited number of small molecule inhibitors of $V$. cholerae biofilms have been reported in the literature, both from natural product screening campaigns and medicinal chemistry development efforts. ${ }^{6,7}$ However in the majority of cases these compounds have been shown to impact quorum sensing $(\mathrm{QS})$ rather than directly targeting processes involved with biofilm matrix production or regulation.

We recently reported the development of two high throughout image-based screens capable of identifying biofilm inhibitors

\footnotetext{
${ }^{a}$ Department of Chemistry and Biochemistry, University of California Santa Cruz, California, 95064, USA.E-mail: rliningt@ucsc.edu

${ }^{b}$ Department of Microbiology and Environmental Toxicology, University of California Santa Cruz, California, 95064, USA

$\dagger$ Electronic supplementary information (ESI) available: Experimental procedures and analytical data along with protocols for all biological experiments. See DOI: $10.1039 / \mathrm{c} 4 \mathrm{cc} 07003 \mathrm{~h}$
}

against the Gram-negative pathogens V. cholerae and Pseudomonas aeruginosa. ${ }^{8-10}$ Screening of our natural product library, compromising of over 6000 prefractions, identified the aureomycin chromophore $\mathbf{1}$ as a moderate inhibitor of $V$. cholerae biofilms (biofilm inhibitory concentration $\left(\mathrm{BIC}_{50}\right)=63 \mu \mathrm{M}$ ). Given the structural novelty of this scaffold compared with other biofilm inhibitors, and the unusual biofilm inhibitory phenotype observed in the primary screening images, we elected to develop the benzo[1,4]oxazine scaffold through medicinal chemistry optimization in order to identify key elements of the required pharmacophore, and generate analogues with improved potency and pharmacological properties. ${ }^{11}$ Key to this approach was the formation of the $\alpha$-keto-amide 7 and its subsequent application in a debenzylationcyclization strategy to form hemi-acetal 8. Gratifyingly, treatment of the $\alpha$-ketoamide 7 (formed in 5 steps from the commercially available ester 2) with $2 \% \operatorname{Pd}(\mathrm{OH})_{2}$ on charcoal and four equivalents of 1,4-cyclohexadiene in ethanol at $50{ }^{\circ} \mathrm{C}$ enabled formation of the cyclic hemi-acetal 8 in excellent yield on a multi-gram scale with reaction times of less than 5 minutes. Dehydration of the acetal afforded the target molecule in 7 steps on a multigram scale (Scheme 1).

To identify key elements of the pharmacophore for this compound class, a library of 41 derivatives were prepared using a divergent strategy to diversify both the exocyclic alkene and the methyl ester moiety of the original scaffold (Fig. 1, see ESI $\dagger$ for a comprehensive list of synthesized compounds). Initial examination of the lead compound 1 highlighted the $\alpha, \beta$ unsaturated carbonyl (C9-C11) as a Michael acceptor with potential involvement in the mechanism of action. In line with the behavior of other Michael acceptors in the literature, modification of the exocyclic methylene unit (compounds 8-12) eliminated activity in all cases. ${ }^{12}$ Introduction of any substituent onto the double bond (compounds 13-17) also resulted in a pronounced decrease in biofilm inhibition, indicating a tight steric limitation for modifications at this position.

To probe whether the increase in steric size of the Michael acceptor directly correlated with the ability of the compound to undergo Michael addition, both the original oxazine $\mathbf{1}$ and phenyl 
<smiles>COC(=O)c1cc(OC)cc(OC)c1</smiles>

2<smiles>COC(=O)c1cc(OC)cc(OC)c1[N+](=O)[O-]</smiles>

3<smiles>COC(=O)c1cc(OC)cc(O)c1[N+](=O)[O-]</smiles><smiles>CC#CC(=O)C(=O)Nc1c(OCc2ccccc2)cc(OC)cc1C(=O)OC</smiles>

7 $\downarrow$ vi)<smiles>COC(=O)c1cc(OC)cc2c1NC(=O)C(C)(O)O2</smiles>

8<smiles>C=C1Oc2cc(OC)cc(C(=O)OC)c2NC1=O</smiles>

1
Scheme 1 The total synthesis of the benzo[1,4] oxazine biofilm inhibitor 1 Reagents and conditions: (i) $\mathrm{HNO}_{3}, \mathrm{Ac}_{2} \mathrm{O}, 0{ }^{\circ} \mathrm{C}$ to rt, 1 hour, $94 \%$ yield; (ii) 4 eq. $\mathrm{AlCl}_{3}, \mathrm{DCM}, 0{ }^{\circ} \mathrm{C}$ to reflux, 3 hours, $89 \%$ yield; (iii) 4 eq. $\mathrm{BnBr}, 4$ eq. $\mathrm{K}_{2} \mathrm{CO}_{3}, 1: 1 \mathrm{DCM} / \mathrm{MeOH}$, reflux, 3 hours, 97\% yield; (iv) 4 eq. $\mathrm{SnCl}_{2}, 3: 1$ $\mathrm{EtOH} / 6 \mathrm{~N} \mathrm{HCl}$, rt to reflux, 45 minutes, $81 \%$ yield; (v) 1.1 eq. pyruvoyl chloride, 1.5 eq. pyridine, $\mathrm{DCM}, 0{ }^{\circ} \mathrm{C}$ to $\mathrm{rt}, 90$ minutes, $65 \%$ yield; (vi) $2 \%$ $\mathrm{Pd}(\mathrm{OH})_{2} / \mathrm{C}, 4$ eq. 1,4 -cyclohexadiene, EtOH, $50{ }^{\circ} \mathrm{C}, 2$ minutes, $81 \%$ yield; (vii) 1.2 eq. $\mathrm{MsCl}, 1.5$ eq. $\mathrm{NEt}_{3}, \mathrm{DCM}, 0{ }^{\circ} \mathrm{C}$ to rt, 90 minutes, $82 \%$ yield.

substituted compound $\mathbf{1 6}$ were added to either $\mathrm{N}$-acetyl cysteine methyl ester or a simple polypeptide (Ac-Ala-Cys-Ala-Gly-OH) and the formation of Michael addition adducts monitored by LC-MS. Complete formation of the expected Michael adduct was observed with compound 1 for both substrates. By contrast very little $(\sim 5 \%)$ of the expected Michael adducts were observed in either case with compound 16, suggesting that the tight steric limitation around the alkene may be due to the inability of sterically encumbered compounds to act as Michael acceptors.

A similar loss in activity was observed upon conversion of the endocyclic amide to the corresponding $N$-methyl derivative (compound 18). This suggests that a hydrogen bond donor may be required to correctly orientate the compound in the active site, or alternatively that this portion of the molecule is present in a congested region of the active site that is not tolerant of increased steric bulk. In contrast to modifications on the oxazine ring, alteration of the ester substituent at $\mathrm{C} 2$ resulted in a pronounced increase in biofilm inhibition. Although conversion of the methyl ester to the corresponding free acid 19 eliminated activity, introduction of the para-methoxy aromatic residue 25 resulted in a 10-fold increase in compound efficacy, with a $\mathrm{BIC}_{50}$ value of $6 \mu \mathrm{M}$. Colony forming unit analysis demonstrated that compound 25 possessed no bactericidal activity up to $200 \mu \mathrm{M}$ (see ESI $\dagger$ ). This was confirmed by BioMAP screening, with compound 25 displaying no activity<smiles>C=C1Oc2cc(OC)cc(C(=O)OC)c2NC1=O</smiles><smiles>COC(=O)c1cc(OC)cc2c1NC(=O)C(C)(O)O2</smiles><smiles>COC(=O)c1cc(OC)cc2c1NC(=O)CO2</smiles><smiles></smiles>

8, $\mathrm{BIC}_{50}=>500 \mu \mathrm{M}$

9, $\mathrm{BIC}_{50}=>500 \mu \mathrm{M}$<smiles>COC(=O)c1cc(OC)cc2c1NC(=O)C(C)O2</smiles><smiles>COC(=O)c1cc(OC)cc2c1NC(=O)C(C)(OC)O2</smiles><smiles>COC(=O)c1cc(O)cc2c1NC(=O)C(c1ccccc1)O2</smiles>

$10, \mathrm{BIC}_{50}=>500 \mu \mathrm{M}$

$11, \mathrm{BIC}_{50}=>500 \mu \mathrm{M}$

$12, \mathrm{BIC}_{50}=>500 \mu \mathrm{M}$<smiles>COC(=O)c1cc(OC)cc2c1NC(=O)/C(=C/C(C)C)O2</smiles>

$13, \mathrm{BIC}_{50}=175 \mu \mathrm{M}$<smiles>C/C=C1/Oc2cc(OC)cc(C(=O)OC)c2NC1=O</smiles><smiles>COC(=O)c1cc(OC)cc2c1NC(=O)C(=C(C)C)O2</smiles>

$14, \mathrm{BIC}_{50}=95 \mu \mathrm{M}$

$15, \mathrm{BIC}_{50}=122 \mu \mathrm{M}$<smiles>[R]C=C1Oc2cc(OC)cc(C(=O)OC)c2NC1=O</smiles>

16, $\mathrm{R}=\mathrm{Ph}, \mathrm{BIC}_{50}=200 \mu \mathrm{M}$

$17 \mathrm{R}=4 \mathrm{NO}_{2}-\mathrm{C}_{6} \mathrm{H}_{4}, \mathrm{BIC}_{50}=195 \mu \mathrm{M}$<smiles>C=C1Oc2cc(OC)cc(C(=O)OC)c2N(C)C1=O</smiles><smiles>C=C1Oc2cc(OC)cc(C(=O)O)c2NC1=O</smiles><smiles>C=C1Oc2cc(OC)cc(C(N)=O)c2NC1=O</smiles>

$18, \mathrm{BIC}_{50}=>500 \mu \mathrm{M}$

19, $\mathrm{BIC}_{50}=>500 \mu \mathrm{M}$

20, $\mathrm{BIC}_{50}=>500 \mu \mathrm{M}$<smiles>C=C1Oc2cc(OC)cc(C(=O)Oc3ccccc3)c2NC1=O</smiles>

21, $\mathrm{BIC}_{50}=45 \mu \mathrm{M}$<smiles>C=C1Oc2cc(OC)cc(C(=O)Oc3cc(Cl)c(Cl)cc3Cl)c2NC1=O</smiles><smiles>C=C1Oc2cc(OC)cc(C(=O)Nc3ccccc3)c2NC1=O</smiles>

23, $\mathrm{BIC}_{50}=>500 \mu \mathrm{M}$

22, $\mathrm{BIC}_{50}=16 \mu \mathrm{M}$

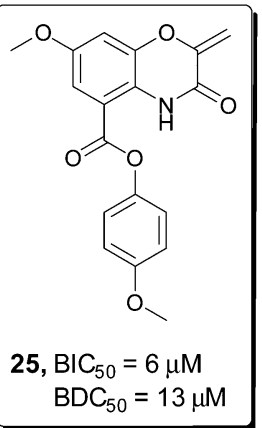

Fig. 1 Screening of a selection of the oxazine inhibitors against $V$. cholerae biofilms. A selection of the oxazine derivatives screened as inhibitors of $V$. cholerae biofilms. $\mathrm{BIC}_{50}$ and $\mathrm{BDC}_{50}$ determined with 3 biological replicates each consisting of two technical replicates, see $\mathrm{ESI} \dagger$ for full $\mathrm{BIC}_{50}$ dose response curves and complete list of all compounds screened in the assay.

against a panel of 15 clinically relevant bacterial pathogens up to $200 \mu \mathrm{M} .{ }^{12}$ Screening in our in-house image-based cytological profiling assay also revealed that compound 25 had no measurable cytotoxicity to HeLa cells, up to $200 \mu \mathrm{M}$ (see ESI $\dagger$ ). ${ }^{13}$ Interestingly, the parent phenyl compound $\mathbf{2 1}$ showed only a marginal increase in activity ( $45 \mu \mathrm{M} v s .62 \mu \mathrm{M}$ ), while the corresponding substituted 
phenyl ester 22 exhibited a 4 -fold increase in activity over the parent methyl ester 1, demonstrating the importance of substituent effects on the aromatic ring.

The observation that the carboxylic acid 19 was inactive as a biofilm inhibitor led us to probe whether hydrolysis of the phenolic ester could be masking the true potency of this compound class. Incubation of oxazine 25 in either LB media or PBS buffer at $37{ }^{\circ} \mathrm{C}$ for 24 hours failed to result in any measurable hydrolysis and suggested that this was not a limiting factor for compound activity. Interestingly, formation of either the phenyl amide $\mathbf{2 3}$ or the analogous para-methoxy amide, two compounds that would be expected to be far more resistant to hydrolysis resulted in a complete loss in compound activity.

One potential application for biofilm inhibitors is as dispersal agents to eliminate biofilms in established infections, which otherwise persist during antibiotic treatment and can lead to recrudescence of infection. We have recently disclosed a novel biofilm dispersal model (BDM) in $P$. aeruginosa that can be used to examine the capabilities of small molecules to induce dispersion of pre-existing biofilms. ${ }^{10}$ To investigate whether compound 25 was capable of the dispersal of pre-formed $V$. cholerae biofilms, a similar procedure was employed in the $V$. cholerae system. In brief, cultures of $V$. cholerae were allowed to pre-form biofilms in screening plates for 2 hours prior to compound addition. Following standard incubation conditions ( 4 hours at $30^{\circ} \mathrm{C}$ ) macrocolonies were imaged and quantified as previously described to determine the percentage of remaining biofilm coverage. Compound 25 displayed strong biofilm dispersal activity and no bactericidal activity, with a biofilm dispersal concentration $\left(\mathrm{BDC}_{50}\right)$ value of $13 \mu \mathrm{M}$ and optical density readings indicating good bacterial growth. To our knowledge this represents the first example of a small molecule capable of both inhibiting and inducing dispersal of $V$. cholerae biofilms, and places it among just a handful of compounds capable of inducing the dispersal of mature surface-associated biofilms. ${ }^{14}$

A major challenge surrounding the treatment of biofilmmediated infections is that bacterial cells within the biofilm have the potential to enter a latent state that renders them much less susceptible to traditional antibiotics. ${ }^{4}$ One potential application for biofilm dispersal agents is as combination therapies with existing antibiotics to both clear and eliminate otherwise persistent infections. To examine whether our biofilm dispersal model could recapitulate this antibiotic resistance for $V$. cholerae we screened five FDA-approved antibiotics (ciprofloxacin, erythromycin, azithromycin, doxycycline and furazilidinone) in the dispersal assay. Interestingly, without the presence of compound 25, erythromycin, ciprofloxacin and furazilidinone (all therapeutics prescribed as first stage treatments for $V$. cholerae infection) failed to induce biofilm dispersal, with confocal microscopy indicating the presence of large biofilm macrocolonies and very few background planktonic cells. Optical density readings confirmed this observation and suggested that these antibiotics have the capacity to eradicate cells in the planktonic state, but not significantly impact biofilm coverage. By contrast, addition of $20 \mu \mathrm{M}$ of compound 25 in addition to $50 \mu \mathrm{M}$ of either erythromycin or ciprofloxacin resulted in near quantitative elimination of biofilm coverage, and a lowering in
A)

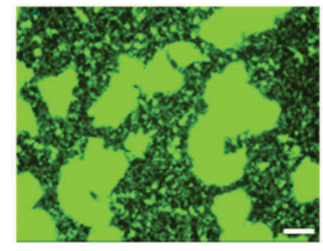

Normalized OD600 Reading

0.99

C)

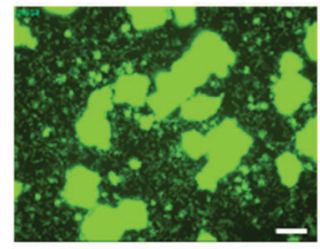

Normalized OD600 Reading

0.63

E)

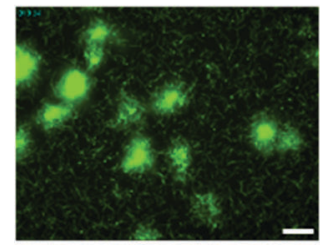

Normalized OD600

Reading

0.14
B)

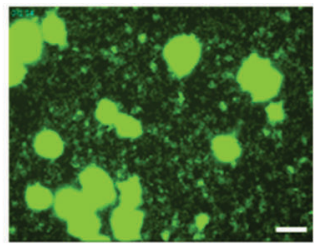

Normalized OD600 Reading

0.58

D)

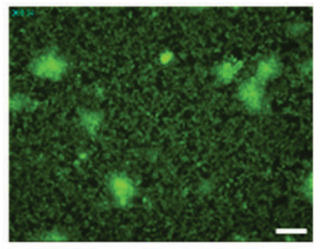

Normalized OD600 Reading

0.93

F)

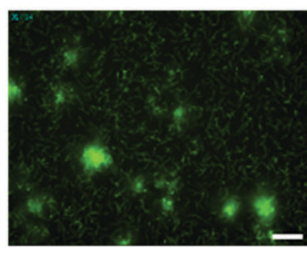

Normalized OD600 Reading

0.17
Fig. 2 Static well images of $V$. cholerae biofilms. Static well GFP images of $V$. cholerae biofilms and normalized $\mathrm{OD}_{600}$ readings. In all instances the antibiotic, dispersal agent or a combination of the two were introduced after two hours of incubation and incubated for a further 4 hours before being washed and analyzed. (A) DMSO control; (B) $50 \mu \mathrm{M}$ ciprofloxacin; (C) $50 \mu \mathrm{M}$ erythromycin; (D) $20 \mu \mathrm{M}$ compound 25; (E) $20 \mu \mathrm{M}$ compound 25 and $50 \mu \mathrm{M}$ ciprofloxacin; (F) $20 \mu \mathrm{M}$ compound 25 and $50 \mu \mathrm{M}$ erythromycin. White bars represent $50 \mu \mathrm{m}$.

the cellular viability, as determined by $\mathrm{OD}_{600}$ analysis, indicating that these drug combinations possess the ability to both clear and kill established $V$. cholerae infections (Fig. 2). One limitation of imagebased high content screening is that samples must be incubated under static culture conditions. The disadvantage of this method is that static culture allows the accumulation of signaling factors and quorum sensing molecules including $V$. cholerae autoinducer-1 (CAI-1), autoinducer-2 (AI-2) and indole which all impact the rate and degree of biofilm formation. ${ }^{15,16}$

To examine whether oxazine 25 was capable of disrupting biofilm formation and persistence under more physiologically relevant conditions, we examined its anti-biofilm properties under flow cell conditions. At all concentrations tested (see ESI $\dagger$ ), strong biofilm inhibition was observed, with a marked decrease in the size, thickness and morphology of the biofilm. COMSTAT analysis ${ }^{17}$ indicated a 7-fold reduction in biomass upon treatment of the $V$. cholerae biofilms with compound 25 under flow conditions (Fig. 3B). These data indicate that compound 25 is capable of disrupting biofilms under both static and flow cell conditions, 
A)

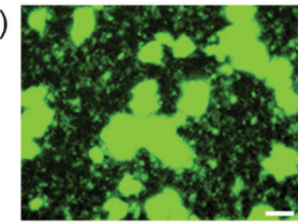

B)

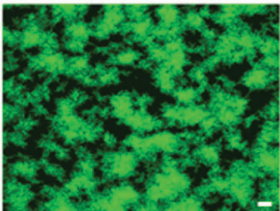

Fig. 3 Static and confocal flow cell images of compound 25 against $V$. cholerae biofilms. (A) static culture conditions, from left to right, DMSO control, compound 25 at $15 \mu \mathrm{M}$. In both instances $\mathrm{OD}_{600}$ data suggested no bactericidal activity; (B) confocal flow cell images of $V$. cholerae, see ESI $\dagger$ for further details. From left to right, DMSO control and lead compound $\mathbf{2 5}$ at $250 \mu \mathrm{M}$. COMSTAT analysis of mean biomass $\left(\mathrm{mm}^{3} / \mathrm{mm}^{2}\right)$ indicated a 7 -fold reduction in the presence of lead compared $\mathbf{2 5}$ compared to DMSO control. In both cases white bars indicate $50 \mu \mathrm{m}$.

and suggest that this compound has potential value as a biofilm inhibitor for the clearance of established biofilm-mediated infections in vivo.

In conclusion, a medicinal chemistry approach is reported for the development of the $V$. cholerae biofilm inhibitor 25 that involves a 7 step, multi-gram, purification-free route to primary lead 1. An SAR study on the oxazine scaffold identified the importance of both the exocyclic alkene and amidic proton for compound activity. Modifications at either position led to complete loss of activity for all tested compounds. However, expansion around the methyl ester identified phenyl ester derivative 25 as an advanced lead compound with one of the highest potencies reported to date for biofilm inhibition against $V$. cholerae $\left(\mathrm{BIC}_{50}=\right.$ $6 \mu \mathrm{M})$ and the capacity to induce the dispersal of preformed biofilms $\left(\mathrm{BDC}_{50}=13 \mu \mathrm{M}\right)$. Co-dosing of compound 25 with $50 \mu \mathrm{M}$ erythromycin or azithromycin demonstrated the potential of the synergistic action of a dispersal reagent and antibiotic in inducing detachment and subsequent clearance of preformed biofilms. Such a strategy may offer a means of overcoming both

the tolerance of biofilms toward traditional antibiotics, and reduce the potential for the development of bacterial resistance often observed with antibiotic mono-therapies.

\section{Notes and references}

1 C. A. Fux, J. W. Costerton, P. S. Stewart and P. Stoodley, Trends Microbiol., 2005, 13, 34-40.

2 M. Wilson, Sci. Prog., 2001, 84, 235-254.

3 T.-F. Mah, Future Microbiol., 2012, 7, 1061-1072.

4 K. Lewis, Curr. Top. Microbiol. Immunol., 2008, 322, 107-131.

5 V. Berk, J. C. N. Fong, G. T. Dempsey, O. N. Develioglu, X. Zhuang, J. Liphardt, F. H. Yildiz and S. Chu, Science, 2012, 337, 236-239.

6 N. Augustine, P. A. Wilson, S. Kerkar and S. Thomas, Curr. Microbiol., 2012, 64, 338-342.

7 (a) V. L. Schramm, J. A. Gutierrez, G. Cordovano, I. Basu, C. Guha, T. J. Belbin, G. B. Evans, P. C. Tyler and R. H. Furneaux, Nucleic Acids Symp. Ser., 2008, 75-76; (b) R. C. Kelly, M. E. Bolitho, D. A. Higgins, W. Lu, W.-L. Ng, P. D. Jeffrey, J. D. Rabinowitz, M. F. Semmelhack, F. M. Hughson and B. L. Bassler, Nat. Chem. Biol., 2009, 5, 891-895; (c) K. Sambanthamoorthy, A. A. Gokhale, W. Lao, V. Parashar, M. B. Neiditch, M. F. Semmelhack, I. Lee and C. M. Waters, Antimicrob. Agents Chemother., 2011, 55, 4369-4378; (d) W.-L. Ng, L. Perez, J. Cong, M. F. Semmelhack and B. L. Bassler, PLoS Pathog., 2012, 8, e1002767; (e) S. T. Rutherford and B. L. Bassler, Cold Spring Harbor Perspect. Med., 2012, 2, a012427.

8 K. C. Peach, A. T. Cheng, A. G. Oliver, F. H. Yildiz and R. G. Linington, ChemBioChem, 2013, 14, 2209-2215.

9 (a) K. C. Peach, W. M. Bray, N. J. Shikuma, N. C. Gassner, R. S. Lokey, F. H. Yildiz and R. G. Linington, Mol. BioSyst., 2011, 7, 1176-1184; (b) B. León, J. C. N. Fong, K. C. Peach, W. R. Wong, F. H. Yildiz and R. G. Linington, Org. Lett., 2013, 15, 1234-1237.

10 G. Navarro, A. T. Cheng, K. C. Peach, W. M. Bray, V. S. Bernan, F. H. Yildiz and R. G. Linington, Antimicrob. Agents Chemother., 2014, 58, 1092-1099.

11 M. Shibuya, H. Sakurai, T. Maeda, E. Nishiwaki and M. Saito, Tetrahedron Lett., 1986, 27, 1351-1354.

12 W. R. Wong, A. G. Oliver and R. G. Linington, Chem. Biol., 2012, 19, 1483-1495.

13 C. J. Schulze, W. M. Bray, M. H. Woerhmann, J. Stuart, R. S. Lokey and R. G. Linington, Chem. Biol., 2013, 20, 285-295.

$14 \mathrm{~J}$. Singh, R. C. Petter, T. A. Baillie and A. Whitty, Nat. Rev. Drug Discovery, 2011, 10, 307-317.

15 (a) R. Frei, A. S. Breitbach and H. E. Blackwell, Angew. Chem., Int. Ed., 2012, 51, 5226-5229; (b) R. E. Furlani, A. A. Yeagley and C. Melander, Eur. J. Med. Chem., 2013, 62, 59-70.

16 M. J. Minvielle, K. Eguren and C. Melander, Chemistry, 2013, 19, 17595-17602.

17 A. Heydorn, A. T. Nielsen, M. Hentzer, C. Sternberg, M. Givskov, B. K. Ersbøll and S. Molin, Microbiology, 2000, 146, 2395-2407. 